\title{
SYNTHESIS, CHARACTERIZATION AND ANTIMICROBIAL ACTIVITY OF SOME NOVEL 3,4-DISUBSTITUTED PYRAZOLE DERIVATIVES
}

\author{
GANESH AKULA ${ }^{1 *}$, KAUSHAL K CHANDRUL ${ }^{2}$, BHIKSHAPATHI DVRN ${ }^{3}$ \\ ${ }^{1}$ Department of Pharmacy, Mewar University, Chittorgarh, Rajasthan, India. ${ }^{2}$ Department of Pharmacy, Mewar University, Chittorgarh, \\ Rajasthan, India. ${ }^{3}$ Department of Pharmacy, Mewar University, Chittorgarh, Rajasthan, India. Email: akulaganesh@gmail.com
}

Received: 30 October 2019, Revised and Accepted: 19 November 2019

\section{ABSTRACT}

Objective: The objective of the current work was to synthesize a series of 3,4-substituted pyrazoles from the cyclization of substituted aryl ethanone and hydrazine hydrate in a two-step process and screen the derivatives for their antimicrobial activity.

Methods: The title compounds were derived from the condensation of ethanone intermediate with N, N-Dimethyl formamide-dimethyl acetal and hydrazine hydrate. Ethanone intermediate synthesized from substituted methyl phenylacetate in the presence of potassium t-butoxide with 6-methyl pyridine-2-carboxylic acid methyl ester.

Results: The final products were characterized by detailed spectral analysis using Mass, Nuclear Magnetic Resonance, and Infra Red spectroscopy. All the compounds (4a-4j) showed significant antibacterial properties on both Gram-positive and Gram-negative bacteria. Interestingly, the selected microbes were found to be highly sensitive for compound 4a, 4c, 4d, 4h, and 4i. The molecules are also antifungal in nature, and they have a significant inhibitory effect on the growth of Candida albicans and Aspergillus niger.

Conclusion: The results suggest that the developed derivatives bearing the pyrazole nucleus could be the lead structures for the development of antimicrobial agents for fatal infections.

Keywords: Pyrazoles, Condensation, Antibacterial, Antifungal.

(c) 2020 The Authors. Published by Innovare Academic Sciences Pvt Ltd. This is an open access article under the CC BY license (http://creativecommons. org/licenses/by/4. 0/) DOI: http://dx.doi.org/10.22159/ajpcr.2020.v13i1.36216

\section{INTRODUCTION}

Various substituted pyrazole based drugs are acquiring significance in medicinal and natural products research by virtue of its multifarious properties and broad spectrum of applications for various ailments [1]. Specifically, substituted pyrazoles create a critical position in the pharmaceutical industry as they comprise the important structure for many commercial drugs such as sildenafil, celecoxib, and rimonabant.

The abundant texts support the ubiquitous nature of aza-heterocyclic compounds, the pyrazole derivatives. They are documented to possess anticancer [2-4], antibacterial [5], antifungal [6,7], antitubercular $[8,9]$, analgesic $[10,11]$, antimalarial $[12,13]$, antipyretic [14], anticonvulsant [15], antidepressant [16], antiangiogenetic [17], antidiabetic [18], antiviral [19,20], and antiinflammatory [21-23] activities.

Since the foundation of the primary synthetic method of pyrazole, i.e., Paal-Knorr synthesis by condensation of 1,3-diketones with hydrazine which yields substituted pyrazoles, it is the subject matter for investigators to create the substituted pyrazoles. Due to the convenience and versatility, Paal-Knorr synthesis had been the principal synthetic method for pyrazole synthesis. There are many customary methodologies for the synthesis of various pyrazole derivatives. A lot of literature in correlation to the variation of Paal-Knorr synthesis with better yields, reported by researchers, by usurping one of the starting material 1,3-diketone with acetylenic and olefinic ketone moieties. Individual substances have been cultivated for producing distinct pyrazole crossbreeds. To overwhelm the severe reaction conditions and to have regioselectivity, a basic and beneficial strategy was utilized for the synthesis of substituted pyrazoles.

\section{EXPERIMENTAL}

Methods

For the current work, synthetic grade chemicals were utilized and purchased from Sigma-Aldrich. Merck-pre-coated aluminum thinlayer chromatography plates of silica gel 60 F254 of 0.5 thickness were employed and spots were observed under ultraviolet light. Pure compounds were isolated from the crude mixture by the column chromatography and the pure compounds were recrystallized with ethanol. Remi electronic melting point apparatus was employed for the melting points determination. Infrared (IR) spectra were recorded on Agilent Fourier-transform IR by $\mathrm{KBr}$ pellet method. Proton nuclear magnetic resonance $\left({ }^{1} \mathrm{H}\right.$ NMR) recorded on VARIAN - $400 \mathrm{MHz}$. The splitting patterns are designated as follows: $s$, singlet; $d$, doublet; $t$, triplet; q, quartet; and $m$, multiplet. MASS recorded on BRUKER ESI-IT MS. The bacterial and fungal strains were obtained from the Department of Microbiology, Osmania University, Hyderabad. The samples were subcultured and preserved at $4^{\circ} \mathrm{C}$.

General procedure for the synthesis of pyrazole derivatives [24] Synthesis of ethanone intermediate

A solution of substituted methyl phenylacetate $(15 \mathrm{mmol})$ potassium t-butoxide (45 $\mathrm{mmol}$ ) and 6-methyl pyridine-2-carboxylic acid methyl ester $(15 \mathrm{mmol})$ in tetrahydrofuran $(75 \mathrm{~mL})$ was heated at $65^{\circ} \mathrm{C}$ for $48 \mathrm{~h}$. The mixture was concentrated under vacuum and treated carefully with concentrated hydrochloric acid $(10 \mathrm{~mL})$. The resulting mixture was heated at $100^{\circ} \mathrm{C}$ for $12 \mathrm{~h}$. The mixture was cooled to room temperature and the $\mathrm{pH}$ adjusted to 9.0 with $6 \mathrm{~N}$ sodium hydroxide solution. The mixture was extracted with ethyl acetate, and the organic layer dried and concentrated under vacuum. The final product was purified by column chromatography with hexane/ethyl acetate mobile phase. 
Synthesis of pyrazole derivatives

A solution of ethanone intermediate $(5 \mathrm{mmol})$ in tetrahydrofuran (20 $\mathrm{mL}$ ) was treated with $\mathrm{N}, \mathrm{N}$-Dimethyl formamide-dimethyl acetal (50 mmol) and stirred for $40 \mathrm{~h}$. The mixture was concentrated under vacuum, diluted with ethanol $(10 \mathrm{~mL})$, and treated with hydrazine monohydrate $(150 \mathrm{mmol})$. The resulting mixture was stirred for $8 \mathrm{~h}$, concentrated, diluted with ethyl acetate, and washed once with water. The combined organic layers concentrated in vacuum and crude product of pyrazole was purified by column chromatography with the mobile phase hexane/ethyl acetate. The complete scheme of synthesis for the title compounds is depicted in Fig. 1.

\section{Antimicrobial screening [25]}

Antibacterial activity

Agar disk diffusion method with standard protocols was employed to screen the antibacterial activity of the titled compounds $(4 \mathrm{a}-4 \mathrm{j})$ at a dose of $100 \mu \mathrm{g} / \mathrm{mL}$ by agar plate method using standard protocols. For the antibacterial screening, two Gram-positive (Staphylococcus aureus and Bacillus subtilis) and two Gram-negative bacterial strains (Escherichia coli and Pipanacoctomys aureus) were selected. Standard neomycin sulfate and dimethyl sulfoxide (DMSO) were served as positive and negative control, respectively. The experiment was done in triplicates and the zone of inhibition measured in mm was taken for the evaluation of the antibacterial activity of the test compounds.

Peptone, meat extract, and sodium chloride were dissolved in distilled water, and $\mathrm{pH}$ of the medium was adjusted to 7.2. Agar was dissolved and distributed in $40 \mathrm{~mL}$ quantities into $100 \mathrm{~mL}$ flasks and was sterilized in an autoclave at $121^{\circ} \mathrm{C}(15 \mathrm{lbs} / \mathrm{sq} . \mathrm{in})$ for $20 \mathrm{~min}$. The medium was inoculated at $1 \%$ level with $18 \mathrm{~h}$ of old cultures of the above-mentioned test organism and transferred into sterile $15 \mathrm{~cm}$ diameter Petri dishes.
The medium in the plates could set at room temperature for $30 \mathrm{~min}$. For the preparation of cup agar plates, $6 \mathrm{~mm}$ diameter holes were made with the help of a sterile borer at the corner of the plate at equal distance. The solution of test compounds was placed in the cups by means of sterile pipettes. In each plate, one cup was used for control with two drops $(0.05 \mathrm{~mL})$ of DMSO neomycin sulfate in $10 \mu \mathrm{g} / \mathrm{mL}$, concentration was used as standard. The plates could incubate at room temperature for $1 \mathrm{~h}$ to diffuse. Then, the plates were incubated for $24 \mathrm{~h}$ at $37^{\circ} \mathrm{C}$ and zone of inhibition was recorded. The experiments were run in duplicate and the average diameter of the zones of inhibition was recorded and noted.

\section{Antifungal activity}

Two fungal strains, Candida albicans and Aspergillus niger were employed to test the antifungal activity of the title compounds in the concentration of $100 \mu \mathrm{g} / \mathrm{mL}$ using the above protocols. The experiments were done in triplicates on A. niger and C. albicans. Standard Nystatin and DMSO were served as positive and negative control, respectively. The zone of inhibition measured in millimeter was taken for the evaluation of an antifungal activity.

Dextrose and agar were added slowly to the filtered solution of peeled potatoes, which were pre-boiled in $200 \mathrm{~mL}$ of water for $30 \mathrm{~min}$. Nystatin in $10 \mu \mathrm{g} / \mathrm{mL}$ concentration and DMSO was taken as standard and control, respectively. The diameter of the zones of inhibition was recorded after the incubation of plates at room temperature $\left(30^{\circ} \mathrm{C}\right)$ for $48 \mathrm{~h}$.

\section{RESULTS AND DISCUSSION}

\section{Synthesis}

Synthesized compounds structure and physicochemical data are depicted in Table 1<smiles>[R]c1ccc(CC(=O)OC(C)=O)cc1</smiles>

$1 \mathbf{a}-\mathbf{j}$<smiles>[R]c1ccc(CC(=O)c2cccc(C)n2)cc1</smiles><smiles>CCCCCN(C)C(OC)OC</smiles><smiles>[R]c1cccc(-c2n[nH]cc2-c2ccccc2)n1</smiles>

Fig. 1: Scheme of synthesis for substituted pyrazoles 
Table 1: Structures and physicochemical data of synthesized compounds

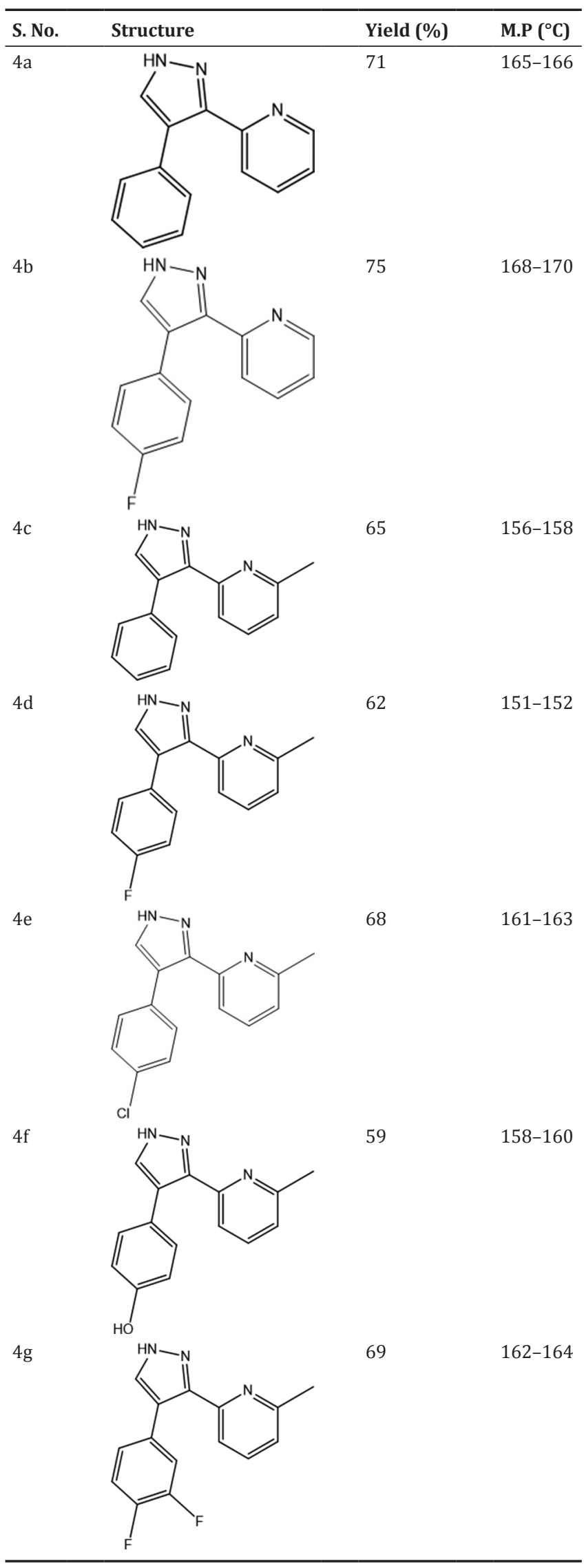

(Contd...)
Table 1: (Continued)

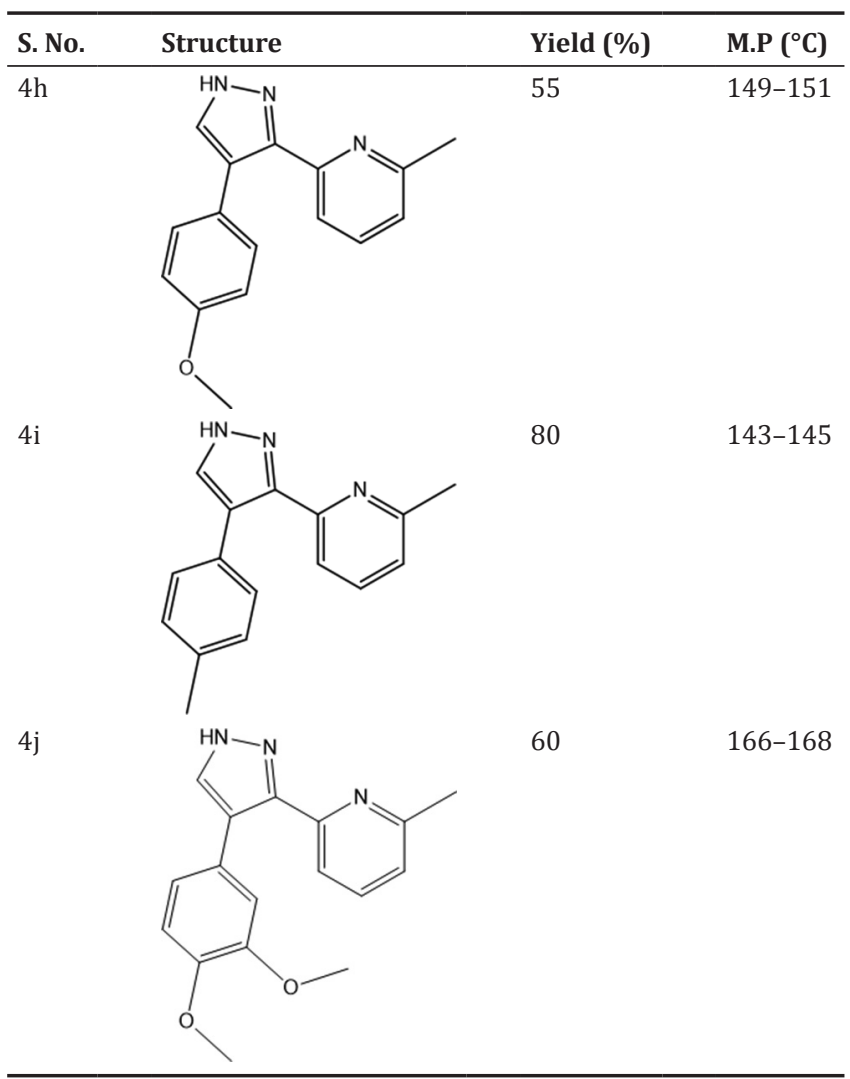

Spectral data

Compound 4a: 2-(4-phenyl-1H-pyrazol-3-yl)pyridine

${ }^{1} \mathrm{H}$ NMR: $\delta 7.23(1 \mathrm{H}, \mathrm{ddd}, J=7.5,4.8,1.5 \mathrm{~Hz}), 7.37-7.54(3 \mathrm{H}, 7.49$ (dddd, $J=7.8,7.5,1.9,0.4 \mathrm{~Hz}$ ), 7.42 (tdd, $J=7.5,1.7,1.4 \mathrm{~Hz}$ ), $7.81(2 \mathrm{H}$, dddd, $J=7.8,2.8,1.7,0.5 \mathrm{~Hz}$ ), 7.86-7.99 2H, 7.96 (ddd, $J=8.1$, 1.5, $0.5 \mathrm{~Hz}$ ), 7.91 (ddd, $J=8.1,7.5,1.8 \mathrm{~Hz}), 8.58(1 \mathrm{H}, \mathrm{s}), 8.70(1 \mathrm{H}, \mathrm{ddd}$, $J=4.8,1.8,0.5 \mathrm{~Hz})$. ESI-MS (m/z): $[\mathrm{M}+\mathrm{H}]^{+}$for $\mathrm{C}_{14} \mathrm{H}_{11} \mathrm{~N}_{3}$ is 222.6 .

Compound 4b: 2-(4-(4-fluorophenyl)-1H-pyrazol-3-yl)pyridine

${ }^{1} \mathrm{H}$ NMR: $\delta 2.19(3 \mathrm{H}, \mathrm{s}), 7.21-7.34(3 \mathrm{H}, 7.30$ (ddd, $J=7.5,4.7,1.3 \mathrm{~Hz}$ ), 7.24 (ddd, $J=8.2,1.3,0.5 \mathrm{~Hz})$ ), $7.81(2 \mathrm{H}, \mathrm{ddd}, J=8.2,1.7,0.4 \mathrm{~Hz}$ ), 7.83-7.95 (2H, 7.92 (ddd, $J=7.9,1.3,0.5 \mathrm{~Hz}$ ), 7.88 (ddd, $J=7.9,7.5$, $1.8 \mathrm{~Hz})$ ), $8.51(1 \mathrm{H}, \mathrm{s}), 8.66(1 \mathrm{H}, \mathrm{ddd}, J=4.7,1.8,0.5 \mathrm{~Hz})$. ESI-MS (m/z): $[\mathrm{M}+\mathrm{H}]^{+}$for $\mathrm{C}_{14} \mathrm{H}_{10} \mathrm{FN}_{3}$ is 240.15 .

Compound 4c: 2-methyl-6-(4-phenyl-1H-pyrazol-3-yl)pyridine

${ }^{1} \mathrm{H}$ NMR: $\delta 2.49(3 \mathrm{H}, \mathrm{s}), 7.31(1 \mathrm{H}, \mathrm{dd}, J=7.8,1.8 \mathrm{~Hz}), 7.39-7.52(3 \mathrm{H}$, 7.47 (dddd, $J=7.8,7.5,1.5,0.4 \mathrm{~Hz}$ ), 7.44 (dddd, $J=7.5,7.2,1.4,1.0 \mathrm{~Hz}$ ), 7.81-7.88 (3H, 7.85 (dd, $J=8.0,1.8 \mathrm{~Hz}$ ), 7.84 (dddd, $J=7.8,2.6,1.0$, $0.5 \mathrm{~Hz})$ ), $7.94(1 \mathrm{H}, \mathrm{dd}, J=8.0,7.8 \mathrm{~Hz}), 8.54(1 \mathrm{H}, \mathrm{s})$. ESI-MS $(\mathrm{m} / \mathrm{z}):[\mathrm{M}+\mathrm{H}]^{+}$ for $\mathrm{C}_{15} \mathrm{H}_{13} \mathrm{~N}_{3}$ is 236.08 .

Compound 4d: 2-(4-(4-fluorophenyl)-1H-pyrazol-3-yl)-6-methylpyridine ${ }^{1} \mathrm{H}$ NMR: $\delta 2.38(3 \mathrm{H}, \mathrm{s}), 7.11(1 \mathrm{H}, \mathrm{dd}, J=7.8,1.5 \mathrm{~Hz}), 7.21(2 \mathrm{H}, \mathrm{ddd}$, $J=8.9,1.5,0.5 \mathrm{~Hz}$ ), 7.41 ( $2 \mathrm{H}, \mathrm{ddd}, J=8.9,1.4,0.5 \mathrm{~Hz}), 7.84(1 \mathrm{H}, \mathrm{dd}, J=7.9$, $1.5 \mathrm{~Hz}), 7.98(1 \mathrm{H}, \mathrm{dd}, J=7.9,7.8 \mathrm{~Hz}), 8.45(1 \mathrm{H}, \mathrm{s}) . \mathrm{ESI}-\mathrm{MS}(\mathrm{m} / \mathrm{z}):[\mathrm{M}+\mathrm{H}]^{+}$ for $\mathrm{C}_{15} \mathrm{H}_{12} \mathrm{FN}_{3}$ is 254.25 .

Compound 4e: 2-(4-(4-chlorophenyl)-1H-pyrazol-3-yl)-6-methylpyridine ${ }^{1} \mathrm{H}$ NMR: $\delta 2.40(3 \mathrm{H}, \mathrm{s}), 7.11(1 \mathrm{H}, \mathrm{dd}, J=7.8,1.5 \mathrm{~Hz}), 7.23(2 \mathrm{H}$, ddd, $J=8.8,1.7,0.5 \mathrm{~Hz}), 7.44(2 \mathrm{H}, \mathrm{ddd}, J=8.8,1.4,0.5 \mathrm{~Hz}), 7.84(1 \mathrm{H}, \mathrm{dd}$, $J=8.0,1.5 \mathrm{~Hz}), 7.97(1 \mathrm{H}, \mathrm{dd}, J=8.0,7.8 \mathrm{~Hz}), 8.48(1 \mathrm{H}, \mathrm{s})$. ESI-MS (m/z): $[\mathrm{M}+\mathrm{H}]^{+}$for $\mathrm{C}_{15} \mathrm{H}_{12} \mathrm{ClN}_{3}$ is 270.6 . 
Table 2: Antibacterial activity of the compounds against Gram-positive and Gram-negative bacteria

\begin{tabular}{|c|c|c|c|c|c|c|c|c|c|c|c|c|}
\hline \multirow[t]{2}{*}{ Bacteria } & \multicolumn{10}{|c|}{ Zone of inhibition of the compounds $(60 \mu \mathrm{g} / \mathrm{mL})$ in $\mathrm{mm}^{\mathrm{a}}$} & \multirow[t]{2}{*}{ Solvent control DMSO } & \multirow[t]{2}{*}{ Neomycin sulfate $10 \mu \mathrm{g} / \mathrm{mL}$} \\
\hline & $\mathbf{4 a}$ & $4 b$ & 4c & 4d & $4 e$ & 4f & $4 g$ & $4 h$ & $4 \mathbf{i}$ & $4 \mathbf{j}$ & & \\
\hline B. subtilis & 14 & 12 & 13 & 15 & 12 & 11 & 11 & 15 & 15 & 11 & 3 & 17 \\
\hline E. coli & 17 & 16 & 18 & 18 & 15 & 13 & 14 & 18 & 18 & 17 & 3 & 19 \\
\hline P. aeruginosa & 13 & 13 & 13 & 14 & 13 & 12 & 12 & 15 & 14 & 12 & 2 & 16 \\
\hline
\end{tabular}

avalues including diameter of the disc (6.0 mm), are averages of triplicates. B. subtilis: Bacillus subtilis, S. aureus: Staphylococcus aureus, E. coli: Escherichia coli,

P. aeruginosa: Pseudomonas aeruginosa, DMSO: Dimethyl sulfoxide

Table 3: Antifungal activity of the compounds

\begin{tabular}{|c|c|c|c|c|c|c|c|c|c|c|c|c|}
\hline \multirow[t]{2}{*}{ Fungus } & \multicolumn{10}{|c|}{ Zone of inhibition of the compounds $(60 \mu \mathrm{g} / \mathrm{mL})$ in $\mathrm{mm}^{\mathrm{a}}$} & \multirow[t]{2}{*}{ Solvent control DMSO } & \multirow[t]{2}{*}{ Nystatin $10 \mu \mathrm{g} / \mathrm{mL}$} \\
\hline & $4 a$ & $4 b$ & $4 c$ & $4 d$ & $4 e$ & $4 f$ & $4 \mathrm{~g}$ & $4 h$ & $4 i$ & $4 \mathbf{j}$ & & \\
\hline A. niger & 14 & 12 & 14 & 15 & 12 & 11 & 11 & 15 & 15 & 11 & 3 & 17 \\
\hline C. albicans & 15 & 13 & 14 & 14 & 11 & 10 & 11 & 15 & 14 & 12 & 2 & 18 \\
\hline
\end{tabular}

${ }^{a}$ Values including diameter of the disc $(6.0 \mathrm{~mm})$, are averages of triplicates. A. niger: Aspergillus niger, C. albicans: Candida albicans, DMSO: Dimethyl sulfoxide

Compound 4f: 4-(3-(6-methylpyridin-2-yl)-1H-pyrazol-4-yl)phenol

${ }^{1} \mathrm{H}$ NMR: $\delta 2.34(3 \mathrm{H}, \mathrm{s}), 7.09(1 \mathrm{H}, \mathrm{dd}, J=7.8,1.8 \mathrm{~Hz}), 7.18(2 \mathrm{H}$, $\mathrm{ddd}, J=8.9,1.5,0.5 \mathrm{~Hz}), 7.75(2 \mathrm{H}, \mathrm{ddd}, J=8.9,1.8,0.5 \mathrm{~Hz}), 7.82(1 \mathrm{H}, \mathrm{dd}$, $J=7.9,1.8 \mathrm{~Hz}), 7.97(1 \mathrm{H}, \mathrm{dd}, J=7.9,7.8 \mathrm{~Hz}), 8.35(1 \mathrm{H}, \mathrm{s})$. ESI-MS $(\mathrm{m} / \mathrm{z})$ : $[\mathrm{M}+\mathrm{H}]^{+}$for $\mathrm{C}_{15} \mathrm{H}_{13} \mathrm{~N}_{3} \mathrm{O}$ is 252.3.

Compound 4g: 2-(4-(3,4-difluorophenyl)-1H-pyrazol-3-yl)-6-methylpyridine ${ }^{1} \mathrm{H}$ NMR: $\delta 2.35(3 \mathrm{H}, \mathrm{s}), 7.09(1 \mathrm{H}, \mathrm{dd}, J=7.8,1.8 \mathrm{~Hz}), 7.18(1 \mathrm{H}, \mathrm{dd}$, $J=8.8,1.8 \mathrm{~Hz}), 7.51(1 \mathrm{H}, \mathrm{dd}, J=8.8,0.5 \mathrm{~Hz}), 7.61(1 \mathrm{H}, \mathrm{dd}, J=1.8,0.5 \mathrm{~Hz})$, $7.83(1 \mathrm{H}, \mathrm{dd}, J=7.9,1.8 \mathrm{~Hz}), 7.97(1 \mathrm{H}, \mathrm{dd}, J=7.9,7.8 \mathrm{~Hz}), 8.45(1 \mathrm{H}, \mathrm{s})$. ESI-MS (m/z): $[\mathrm{M}+\mathrm{H}]^{+}$for $\mathrm{C}_{15} \mathrm{H}_{11} \mathrm{~F}_{2} \mathrm{~N}_{3}$ is 272.1 .

Compound 4h: 2-(4-(4-methoxyphenyl)-1H-pyrazol-3-yl)-6-methylpyridine ${ }^{1} \mathrm{H}$ NMR: $\delta 2.32(3 \mathrm{H}, \mathrm{s}), 3.72(3 \mathrm{H}, \mathrm{s}), 7.07(1 \mathrm{H}, \mathrm{dd}, J=7.8,1.8 \mathrm{~Hz})$, $7.15(2 \mathrm{H}, \mathrm{ddd}, J=8.9,1.5,0.5 \mathrm{~Hz}), 7.64(2 \mathrm{H}, \mathrm{ddd}, J=8.9,1.7,0.5 \mathrm{~Hz})$, $7.81(1 \mathrm{H}, \mathrm{dd}, J=7.9,1.8 \mathrm{~Hz}), 7.96(1 \mathrm{H}, \mathrm{dd}, J=7.9,7.8 \mathrm{~Hz}), 8.37(1 \mathrm{H}, \mathrm{s})$. ESI-MS (m/z): [M+H] $]^{+}$for $\mathrm{C}_{16} \mathrm{H}_{15} \mathrm{~N}_{3} \mathrm{Ois} 266.3$.

Compound 4i: 2-(4-(3,4-dimethoxyphenyl)-1H-pyrazol-3-yl)-6-methylpyridine ${ }^{1} \mathrm{H}$ NMR: $\delta 2.30(3 \mathrm{H}, \mathrm{s}), 3.69(3 \mathrm{H}, \mathrm{s}), 3.73(3 \mathrm{H}, \mathrm{s}), 6.88(1 \mathrm{H}, \mathrm{dd}, J=8.8$, $0.4 \mathrm{~Hz}), 7.02(1 \mathrm{H}, \mathrm{dd}, J=7.8,1.7 \mathrm{~Hz}), 7.23(1 \mathrm{H}, \mathrm{dd}, J=1.9,0.4 \mathrm{~Hz})$, $7.29(1 \mathrm{H}, \mathrm{dd}, J=8.8,1.9 \mathrm{~Hz}), 7.93(1 \mathrm{H}, \mathrm{dd}, J=7.8,7.7 \mathrm{~Hz}), 8.02(1 \mathrm{H}, \mathrm{dd}$, $J=7.7,1.7 \mathrm{~Hz}), 8.28(1 \mathrm{H}, \mathrm{s})$. ESI-MS $(\mathrm{m} / \mathrm{z}):[\mathrm{M}+\mathrm{H}]^{+}$for $\mathrm{C}_{16} \mathrm{H}_{15} \mathrm{~N}_{3}$ is 250.2 .

Compound 4j: 2-methyl-6-(4-(p-tolyl)-1H-pyrazol-3-yl) pyridine

${ }^{1} \mathrm{H}$ NMR: $\delta 2.18(3 \mathrm{H}, \mathrm{s}), 2.40(3 \mathrm{H}, \mathrm{s}), 7.07(1 \mathrm{H}, \mathrm{dd}, J=7.8,1.2 \mathrm{~Hz})$, $7.19(2 \mathrm{H}$, ddd, $J=8.2,1.3,0.5 \mathrm{~Hz}), 7.76-7.84(3 \mathrm{H}, 7.82(\mathrm{dd}, J=7.9$, $1.2 \mathrm{~Hz}$ ), 7.79 (ddd, $J=8.2,1.6,0.5 \mathrm{~Hz})$ ), $7.96(1 \mathrm{H}, \mathrm{dd}, J=7.9,7.8 \mathrm{~Hz}$ ), $8.46(1 \mathrm{H}, \mathrm{s})$. ESI-MS (m/z): $[\mathrm{M}+\mathrm{H}]^{+}$for $\mathrm{C}_{17} \mathrm{H}_{17} \mathrm{~N}_{3} \mathrm{O}_{2}$ is 296.4 .

\section{Antibacterial activity}

The antibacterial screening of the compounds (4a-4j) was screened against two Gram-positive, namely, S. aureus and B. subtilis, two Gram-negative, namely, Pseudomonas aeruginosa and E. coli using agar plate method. All the synthesized compounds display considerable antibacterial properties. Interestingly, compounds $4 \mathrm{a}, 4 \mathrm{c}, 4 \mathrm{~d}, 4 \mathrm{~h}$, and $4 \mathrm{i}$ are showing comparatively higher inhibition to both Gram-positive and Gram-negative bacteria. The results are tabulated in Table 2.

The results of antifungal screening performed against $C$. albicans and A. niger are depicted in Table 3. Results display the antimicrobial potential of the title compounds against selected bacterial and fungal strains. The phenyl ring substituted with both electron-donating and electron-withdrawing groups produced considerable antimicrobial activity. From the above results, the substituted derivatives of pyrazoles are antimicrobial in nature. Remarkably, the compounds $4 \mathrm{a}, 4 \mathrm{c}, 4 \mathrm{~d}, 4 \mathrm{~h}$, and $4 \mathrm{i}$ displayed good antimicrobial potential. The above findings can clear that these pyrazole derivatives can serve as lead molecules to the development of potent antimicrobial agents.

\section{CONCLUSION}

Various substituted pyrazole derivatives have been synthesized in a two-step process involving the cyclization of ethenone intermediate with hydrazine moiety. The simple procedure under reflux conditions leads to the synthesis 10 derivatives $(4 a-4 j)$. The structures were established by detailed spectral analysis. Antimicrobial studies were performed on the synthesized compounds against selected microbial strains and the results revealed the antibacterial, antifungal properties. From the results, it can be concluded that further investigation is needed to understand the exact mechanism of the antimicrobial property in molecular level to develop potent antimicrobial agents to eradicate the pathogenic diseases caused by the bacteria and fungi.

\section{AUTHORS' CONTRIBUTION}

Under the Guidance of the Dr. Kaushal K Chandrul and Dr. DVRN Bhikshapathi, The corresponding author Ganesh Akula contributed majorly in this research work.

\section{CONFLICTS OF INTEREST}

All the authors Ganesh Akula, Kaushal $\mathrm{K}$ Chandrul and DVRN Bhikshapathi express no conflicts of interest.

\section{REFERENCES}

1. Ansari A, Ali A, Asif M, Shamsuzzaman S. Review: Biologically active pyrazole derivatives. New J Chem 2017;41:16-41.

2. el-Moghazy SM, Barsoum FF, Abdel-Rahman HM, Marzouk A. Synthesis and anti-inflammatory activity of some pyrazole derivatives. Med Chem Res 2012;21:1722-33.

3. Kumar RS, Arif IA, Ahamed A, Idhayadhulla A. Anti-inflammatory and antimicrobial activities of novel pyrazole analogues. Saudi J. Bio Sci 2016;23:614-20.

4. Ardiansah B. Recent reports on pyrazole-based bioactive compounds as candidate for anticancer agents. Asian J Pharm Clin Res 2017;10:45-51.

5. Mahaveer P, Kulkarni RG, Radakrishna P, Chandrashekar VM, Achaiah G. Synthesis, characterization and anti-inflammatory activity of novel pyrazolyl ketoamides. Indian J Chem 2013;52:818-23.

6. Rahimizadeh M, Pordel M, Bakavoli M, Rezaeian S, Sadeghian A. Synthesis and antibacterial activity of some new derivatives of pyrazole. World J Microbiol Biotechnol 2010;26:317-21.

7. Sharma KP, Sharma HK. Some hexa-coordinated lanthanide (III) iodide complexes with schiff bases of cyanoethylated benzaldehyde. Asian J Chem 2007; 19:4129-34

8. Bhaskar VH, More VS, Kumar M. Biological activities of 4-(substitued 
phenyl)-5-(2,4- dinitrophenyl)-3-methyl-1,3a,4,5-tetrahydropyrazolo[3,4-c] pyrazole. Asian J Chem 2008;20:5474-85.

9. Solanki PR, Wadodkar KN, Rai MK, Wagh P. Synthesis and biological evaluation of some tri- and tetra-substituted pyrazoles and isoxazoles. Asian J Chem 2003;15:1864-73

10. Janus SL, Magdif AZ, Erik BP, Claus N. Synthesis of triazenopyrazole derivatives as potential inhibitors of HIV-1. Monatsh Chem 1999;130:1167-74

11. el-Sabbagh OI, Baraka MM, Ibrahim SM, Pannecouque C, Andrei G, Snoeck R, et al. Synthesis and antiviral activity of new pyrazole and thiazole derivatives. Eur J Med Chem 2009;44:3746-54.

12. Bekhit AA, Hymete A, Asfaw H, Bekhit AE. Evaluation of some $1 \mathrm{H}$-pyrazole derivatives as a dual acting antimalarial and anti Leishmania agent. Arch Pharm Med Chem 2012;345:147-52.

13. Vaidya AB, Morrisey JM, Zhang W, Das S, Daly TM, et al. Pyrazoleamide compounds are potent antimalarials that target $\mathrm{Na}+$ homeostasis in intraerythrocytic Plasmodium falciparum. Nat Commun 2014:5:5521-30.

14. Gawad NM, Hassan GS, Georgy HH. Review: Biologically active pyrazole derivatives. Med Chem Res 2012;21:983-94.

15. Selvam TP, Kumar PV, Saravanan G, Prakash CR. Microwave-assisted synthesis, characterization and biological activity of novel pyrazole derivatives. J Saudi Chem Soc 2014;18:1015-21.

16. Jayanna ND, Vagdevi HM, Dharshan JC, Raghavendra R, Telkar SB. Synthesis, antimicrobial, analgesic activity, and molecular docking studies of novel 1-(5,7-dichloro-1,3-benzoxazol-2-yl)-3-phenyl-1Hpyrazole-4-carbaldehyde. Med Chem Res 2013;22:5814-22.

17. Malvar D, Ferreira RT, de Castro RA, de Castro LL, Freitas AA,
Costa EA, et al. Antinociceptive, anti-inflammatory and antipyretic effects of 1.5-diphenyl-1H-Pyrazole-3-carbohydrazide, a new heterocyclic pyrazole derivative. Life Sci 2014;95:81-8

18. Menozzi G, Mosti L, Schenone P, D’Amico M, Filippelli A, Rossi F. 4H-thieno[3,4- c]pyrazole derivates with antiinflammatory, analgesic, antipyretic and platelet antiaggregating activities. Farmaco 1992;47:1495-511

19. Geha RM, Chen K, Wouters J, Ooms F, Shih J. Analysis of conserved active site residues in monoamine oxidase $\mathrm{A}$ and $\mathrm{B}$ and their threedimensional molecular modeling. J Biol Chem 2002;277:17209-16

20. Foley P, Gerlach M, Youdim MB, Riederer P. MAO-B inhibitors: Multiple roles in the therapy of neurodegenerative disorders? Parkinsonism Relat Disord 2008;6:25-47.

21. Palaska E, Aydin F, Ucar G, Erol D. Synthesis and screening of human monoamine oxidase-a inhibitor effect of new 2-pyrazoline and hydrazone derivatives. Arch Pharm Chem Life Sci 2008;341:209-17.

22. Aragade P, Sadhana K, Hemant K, Dwarkadas B, Veeresh M. Synthesis, antiinflammatory, analgesic and antipyretic activity of novel 1,3,5-trisubstituted pyrazole derivatives. Int J Drug Des Discov 2012;3:688-78.

23. Alagarsamy V, Saravanan G. Synthesis and anticonvulsant activity of novel quinazolin-4 (3H)-one derived pyrazole analogs. Med Chem Res 2013;22:1711-22.

24. Gurunanjappa P, Nagamallu R, Kariyappa AK. Synthesis and antimicrobial activity of novel fused pyrazoles. Int J Pharm Pharm Sci 2014;7:379-81.

25. Kumar DS, Suresh K. Synthesis and in vitro antifungal activity of chalcone derivatives linked with 1, 2, 4 triazole. Asia J pharm Anal Med Chem 2017;5:60-4. 